\title{
ANALYSIS OF INTELLECTUAL CAPITAL EFFECT TOWARD FINANCIAL PERFORMANCE AND GROWTH
}

\author{
Sasya Sabrina \\ Accounting Department, Faculty of Economic and Comunication, BINUS University \\ Jln. K.H. Syahdan No 9, Palmerah, Jakarta Barat 11480 \\ sasyasabrina@gmail.com
}

\begin{abstract}
The purpose of this research is to investigate the influence of intellectual capital of firm toward financial performance and growth. The Value Added Intellectual Coefficient (VAIC ${ }^{T M}$ ) is used to measure intellectual capital. The indicators for VAIC ${ }^{T M}$ are Value Added Capital Employed (VACA), Value Added Human Capital (VAHU), and Structural Capital Value Added (STVA). The indicators for financial performance are Current Ratio (CR), Total Assets Turnover (TATO), Return on Investment (ROI), and Return on Equity (ROE). The indicators for growth are Earnings Growth $(E G)$ and Assets Growth $(A G)$. This research uses data drawn from 92 publicly listed manufacturing companies in Indonesian Stock Exchange in 2010, 2011, and 2012. Partial Least Square (PLS) is used as the method of data analysis. This research uses SmartPLS 3.2.0 to analyze the data.The results show that: intellectual capital doesn't influence financial performance and intellectual capital positively influences growth.
\end{abstract}

Keywords: intellectual capital, financial performance, growth, partial least square

\begin{abstract}
ABSTRAK
Tujuan dari penelitian ini adalah untuk mengetahui pengaruh intellectual capital terhadap financial performance dan growth. Value Added Intellectual Coefficient (VAIC ${ }^{T M}$ ) digunakan untuk mengukur intellectual capital. Indikator untuk VAIC ${ }^{T M}$ adalah Value Added Capital Employed (VACA), Value Added Human Capital (VAHU), dan Structural Capital Value Added (STVA). Indikator untuk financial performance adalah Current Ratio (CR), Total Assets Turnover (TATO), Return on Investment (ROI), dan Return on Equity (ROE). Indikator untuk growth adalah Earnings Growth (EG) dan Assets Growth (AG). Penelitian ini menggunakan data dari 92 perusahaan manufaktur yang terdaftar di Bursa Efek Indonesia tahun 2010, 2011, dan 2012. Partial Least Square (PLS) digunakan sebagai metode analisis data dengan menggunakan software Smart PLS 3.2.0. Hasil penelitian ini adalah: intellectual capital tidak mempengaruhi financial performance dan intellectual capital mempengaruhi pertumbuhan secara positif.
\end{abstract}

Kata kunci: intellectual capital, financial performance, growth, partial least square 


\section{PENDAHULUAN}

Perekonomian yang telah mengalami perkembangan menuntut perusahaan, khususnya perusahaan terbuka untuk berlomba-lomba melakukan perubahan dalam pengelolaan suatu bisnis untuk mencapai keberhasilan (Solikhah, Rohman, \& Meiranto, 2010). Keberhasilan suatu perusahaan dapat diukur dari kinerja perusahaan atau pertumbuhan perusahaan. Informasi mengenai kinerja perusahaan dapat diperoleh dengan mudah dari laporan keuangan atau annual report yang diterbitkan oleh perusahaan.

Para pelaku bisnis mulai menyadari bahwa kemampuan bersaing tidak hanya terletak pada kepemilikan aktiva berwujud, tetapi lebih pada inovasi, sistem informasi, pengelolaan organisasi dan sumber daya organisasi yang dimiliki. Oleh karena itu organisasi bisnis semakin menitik beratkan pentingnya aset pengetahuan sebagai salah satu bentuk dari aktiva tidak berwujud (Agnes, 2008). Proses manual yang dikerjakan dalam suatu bisnis telah diganti dengan proses yang terotomatisasi. Pekerja manusia digantikan oleh mesin-mesin canggih. Perkembangan teknologi yang begitu pesat tidak lain disebabkan oleh berkembangnya pengetahuan yang dimiliki manusia (Pulic, 1998). Maka dari itu, perusahaan mulai mengembangkan aset pengetahuan (knowledge asset) untuk mendukung perusahaan dalam mencapai tujuannya.

Pengetahuan yang dimiliki oleh karyawan perusahaan dapat dikembangkan menjadi aset bagi perusahaan tersebut. Maka dari itu, karyawan dibekali dengan berbagai pengetahuan dan training yang akan menjadi bekal bagi perusahaan untuk bersaing dengan perusahaan kompetitor. Perusahaan rela mengeluarkan banyak biaya untuk memberikan training kepada karyawan. Pengetahuan yang diperoleh dari training tersebut diharapkan dapat menjadi aset bagi perusahaan dalam mencapai kinerja yang baik dan pertumbuhan yang pesat, serta memiliki nilai pasar saham yang tinggi. Untuk menilai dan mengukur aset pengetahuan, pendekatan yang dapat digunakan adalah intellectual capital (Petty dan Guthrie, 2000). Pengukuran yang tepat untuk intellectual capital ini masih terus dikembangkan. Pulic (1998) mengusulkan untuk menggunakan Value Added Intellectual Coefficient $\left(\mathrm{VAIC}^{\mathrm{TM}}\right)$ untuk mengukur intellectual capital perusahaan.

Penelitian tentang hubungan intellectual capital dengan kinerja dan pertumbuhan perusahaan juga masih menghasilkan kesimpulan yang berbeda-beda. Di Amerika Serikat, penelitian yang dilakukan oleh Riahi-Belkaoui (2003) menunjukkan bahwa intellectual capital berhubungan secara signifikan dengan kinerja keuangan 81 perusahaan multinasional di Amerika Serikat. Penelitian yang dilakukan oleh Chen, Cheng, \& Hwang (2005) di Taiwan menunjukkan bahwa intellectual capital berpengaruh terhadap nilai pasar, kinerja perusahaan dan kinerja perusahaan di masa depan. Di Indonesia, berdasarkan hasil penelitian yang dilakukan oleh Solikhah et. al., (2010) diketahui bahwa intellectual capital berpengaruh positif terhadap kinerja keuangan dan pertumbuhan perusahaan. Intellectual capital tidak berpengaruh terhadap nilai pasar perusahaan. Menurut Iswati \& Anshori (2007), intellectual capital mempengaruhi kinerja keuangan perusahaan asuransi di Bursa Efek Indonesia.

\section{Definisi dan Komponen Intellectual Capital}

"Intellectual capital is essentially defined as the knowledge assets that can be converted into value" (Edvinsson \& Sullivan, dalam Cabrita \& Bontis, 2008). Cabrita \& Bontis (2008) menyimpulkan bahwa intellectual capital dapat menciptakan dan mendukung hubungan antara serangkaian keahlian, pengalaman dan kompetensi dalam dan luar perusahaan. Menurut Marr dan Schiuma dalam Solikhah et. al. (2010), intellectual capital merupakan "Sekelompok aset pengetahuan yang merupakan atribut organisasi dan berkontribusi signifikan untuk meningkatkan posisi persaingan dengan menambahkan nilai bagi stakeholder”. Sedangkan menurut Smedlund \& Poyhonen dalam 
Rupidara (2008), mewacanakan modal intelektual sebagai "kapabilitas organisasi untuk menciptakan, melakukan transfer, dan mengimplementasikan pengetahuan".

Menurut Brennan \& Connell (2000), dua kerangka yang paling banyak dikutip untuk mengelola intellectual capital adalah model Skandia dan Dow Chemical. Model Skandia dikembangkan oleh Edvinsson pada tahun 1993. Pada model ini, intellectual capital dibagi menjadi structural capital dan human capital. Structural capital terdiri dari customer capital dan organizational capital, yang menggambarkan fokus eksternal dan internal dari structural capital. Organizational capital terdiri dari innovation capital dan process capital. Model intellectual capital Dow Chemical yang dikembangkan oleh Petrash, berfokus pada manajemen taktis aset intelektual untuk mencapai tujuan strategis.

\section{Value Added Intellectual Coefficient (VAIC ${ }^{\mathrm{TM}}$ )}

Pulic (1998), mengembangkan Value Added Intellectual Coefficient (VAIC ${ }^{\mathrm{TM}}$ ) untuk mengukur intellectual capital perusahaan. Metode $\mathrm{VAIC}^{\mathrm{TM}}$ didesain untuk menyediakan informasi tentang efisiensi penciptaan nilai aset berwujud dan tidak berwujud dalam suatu perusahaan. Metode ini dimulai dari kemampuan perusahaan untuk menciptakan nilai tambah (value added/ VA) dan mengukur efisiensi dari tiga tipe input perusahaan, yaitu: physical and financial capital, human capital, dan structural capital (Pulic dalam Chen et. al., 2005; Tan, Plowman, \& Hancock, 2007). Menurut Pulic (sebagaimana dikutip dari Chen et. al., 2005; Tan et. al., 2007), value added merupakan perbedaan antara output (OUT) dan input (IN). Output (OUT) merepresentasikan pendapatan dan mencakup semua produk dan jasa yang dijual di pasar, sedangkan input (IN) terdiri dari semua beban yang terjadi dalam menghasilkan pendapatan kecuali beban karyawan. Beban karyawan tidak disertakan pada input (IN) karena karyawan berperan aktif dalam proses penciptaan nilai (value creating process), sehingga labour expenses tidak diperhitungkan sebagai biaya (cost). Aspek kunci dalam model Pulic ini adalah memperlakukan karyawan sebagai entitas penciptaan nilai (value creating entity).

Hubungan value added (VA) dengan tiga tipe input perusahaan adalah sebagai berikut (Pulic dalam Chen et. al, 2005; Tan et al, 2007): (1) Value Added Capital Employed (VACA). VACA merupakan hubungan antara value added (VA) dengan physical capital (CA) dan menunjukkan berapa banyak value added (VA) yang dihasilkan dari satu unit physical capital. (2) Value Added Human Capital (VAHU). VAHU merupakan hubungan antara value added (VA) dengan human capital (HC) dan menunjukkan berapa banyak value added (VA) yang dihasilkan dari satu unit dana yang dikeluarkan untuk karyawan. Indikator dari $\mathrm{HC}$ adalah total gaji atau upah yang dikeluarkan perusahaan. (3) Structural Capital Value Added (STVA). STVA menunjukkan kontribusi structural capital (SC) dalam penciptaan nilai (value creation).

Keunggulan dari metode VAIC ${ }^{\mathrm{TM}}$ ini adalah kemudahan dalam memperoleh data dan memungkinkan dilakukan analisis lebih lanjut pada sumber data yang lain. Data yang diperlukan untuk perhitungan tersebut adalah angka-angka standar yang tersedia pada laporan keuangan yang sudah diaudit.

\section{Pengaruh Intellectual Capital $\left(\mathrm{VAIC}^{\mathrm{TM}}\right)$ terhadap Financial Performance}

Menurut Solikhah et al. (2010), kinerja keuangan perusahaan adalah "suatu tampilan atau keadaan secara utuh atas keuangan perusahaan selama periode/ kurun waktu tertentu". Pada penelitian yang dilakukan oleh Chen et. al. (2005) dengan menggunakan data yang diperoleh dari perusahaan Taiwan yang terbuka, menunjukkan hasil sebagai berikut: 


\begin{abstract}
"Intellectual capital is increasingly recognized as an important strategic asset for sustainable corporate competitive advantages. Our study provides empirical evidence that investors place higher value on firms with better intellectual capital efficiency, and that firms with better intellectual capital efficiency yield greater profitability and revenue growth in both the current and the following years. Our results underline the importance of intellectual capital in enhancing firm profitability and revenue growth. Although generally-accepted accounting standards restrain most intellectual capital from being recognized in financial statements, investors still grasp the invisible value of intellectual capital" (Chen et. al., 2005).
\end{abstract}

Hasil penelitian di atas menunjukkan bahwa intellectual capital merupakan aset strategis yang penting untuk keunggulan kompetitif perusahaan yang berkelanjutan. Selain itu, intellectual capital juga berperan penting dalam meningkatkan profitabilitas dan pertumbuhan pendapatan.

Hipotesis 1: Intellectual capital berpengaruh terhadap financial performance.

\title{
Pengaruh Intellectual Capital terhadap Firms' Growth
}

Menurut Kallapur \& Trombley (2001), growth berarti "the ability of the firm to increase in size". Pada penelitian yang dilakukan oleh Chen et. al. (2005), intellectual capital berperan penting dalam meningkatkan pertumbuhan pendapatan (sales). Menurut Solikhah et. al. (2010), intellectual capital terbukti signifikan berpengaruh positif terhadap pertumbuhan perusahaan. Perusahaan yang mampu mengelola sumber daya intelektualnya dengan maksimal, akan memperoleh value added secara teratur dan berkesinambungan sehingga perusahaan mampu untuk tumbuh dan tetap survive.

Hipotesis 2: $\quad$ Intellectual capital berpengaruh terhadap growth.

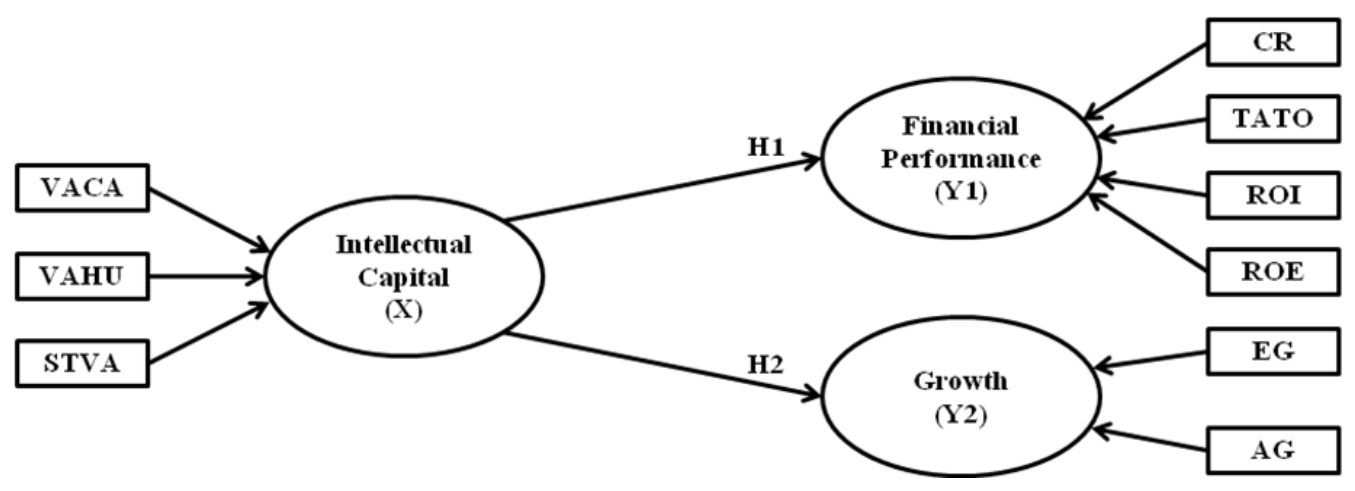

Gambar 1 Model Penelitian

\section{METODE}

\section{Sampel dan Teknik Pemilihan Sampel}

Populasi dari penelitian ini adalah perusahaan manufaktur yang terdaftar di Bursa Efek Indonesia selama tahun 2010, 2011, dan 2012. Sampel yang digunakan akan dipilih dengan metode pemilihan sampel purposive sampling. Dengan metode ini, sampel dipilih secara tidak acak, yaitu dengan menggunakan pertimbangan tertentu yang biasanya disesuaikan dengan tujuan dan masalah penelitian. Kriteria pemilihan sampel untuk penelitian ini adalah: (1) Perusahaan tidak melakukan merger atau akuisisi selama tahun 2010, 2011, dan 2012. (2) Perusahaan tidak delisting dari Bursa 
Efek Indonesia selama tahun 2010, 2011, dan 2012. (3) Perusahaan tidak di-suspend dari perdagangan selama tiga tahun, yaitu tahun 2010, 2011, dan 2012. (4) Perusahaan listing di Bursa Efek Indonesia sebelum tahun 2009.

\section{Variabel Independen}

Variabel independen dalam penelitian ini adalah intellectual capital yang diukur dengan metode VAIC ${ }^{\mathrm{TM}}$ yang dikembangkan oleh Pulic (Dalam Chen et al., 2005; Tan et al., 2007). Metode VAIC $^{\mathrm{TM}}$ didesain untuk menyediakan informasi tentang efisiensi penciptaan nilai aset berwujud dan tidak berwujud dalam suatu perusahaan. Indikator-indikator dari VAIC ${ }^{\mathrm{TM}}$ adalah: Value Added Capital Employed (VACA), Value Added Human Capital (VAHU), dan Structural Capital Value Added (STVA).

\section{Variabel Dependen}

Variabel dependen pertama adalah financial performance. Indikator dari financial performance adalah: Current Ratio (CR), Total Assets Turnover (TATO), Return on Investment (ROI), dan Return on Equity (ROE). Variabel dependen kedua adalah growth dan dengan indikator Earnings Growth (EG) dan Assets Growth (AG).

\section{Metode Analisis Statistik Deskriptif}

Statistik deskriptif digunakan untuk memberikan gambaran profil data sampel yang digunakan pada penelitian ini. Statistik deskriptif yang digunakan pada penelitian ini adalah rata-rata (mean), standar deviasi, nilai maksimum, dan nilai minimum. Analisis statistik deskriptif hanya digunakan untuk memberikan gambaran data sampel, bukan untuk membuat kesimpulan untuk penelitian.

\section{Metode Analisis Statistik Inferensial}

Metode analisis pada penelitian ini adalah Partial Least Square/ PLS (Structural Equation Modeling yang berbasis component atau variance) dengan menggunakan SmartPLS versi 3.2.0. Metode ini dipilih dengan pertimbangan bahwa variabel-variabel laten pada penelitian ini baik independen maupun dependen dibentuk oleh indikator-indikator yang bersifat formatif atau indikatorindikator yang mempengaruhi variabel laten. Structural Equation Modeling yang berbasis covariance hanya mampu menganalisis variabel laten yang memiliki indikator-indikator yang bersifat refleksif (Ghozali, 2011).

Pengambilan keputusan atas penerimaan atau penolakan hipotesis dilakukan dengan ketentuan berikut: (1) Melihat nilai outer weight masing-masing indikator dan nilai signifikansinya. Nilai yang disarankan adalah $T$-statistic di atas 1.96. Indikator yang memiliki nilai di bawah ketentuan tersebut harus dikeluarkan dari model dan kemudian dilakukan pengujian ulang dengan indikator yang signifikan atau mendekati signifikan. (2) Melihat nilai inner weight dari hubungan antar variabel laten dengan melihat nilai $R$-square dan nilai $T$-statistic. Hipotesis alternatif (Ha) diterima jika nilai $T$ statistic di atas 1.96. $\mathrm{H}_{0}$ diterima jika nilai T-statistic di bawah 1.96 . 


\section{HASIL DAN PEMBAHASAN}

\section{Gambaran Umum Unit Penelitian}

Data pada penelitian diperoleh dari laporan keuangan tahun 2010, 2011, 2012 yang diterbitkan oleh perusahaan manufaktur yang terdaftar di Bursa Efek Indonesia. Harga saham yang diambil untuk penelitian ini adalah harga saham penutupan per tanggal 31 Maret 2011 untuk periode penelitian 2010, per tanggal 30 Maret 2012 untuk periode penelitian 2011, dan per tanggal 29 Maret 2013 untuk periode penelitian 2012.

Tabel 1 Sampel Penelitian

\begin{tabular}{|c|c|c|c|}
\hline No. & Kriteria & Jumlah & Akumulasi \\
\hline 1 & Perusahaan manufaktur yang terdaftar di BEI pada tahun 2012 & & 136 \\
\hline 2 & $\begin{array}{l}\text { Perusahaan yang melakukan merger atau akuisisi selama tahun 2010, 2011, } \\
\text { dan } 2012\end{array}$ & 6 & 130 \\
\hline 3 & Perusahaan yang delisting pada tahun 2012 & 1 & 129 \\
\hline 4 & $\begin{array}{l}\text { Perusahaan yang di-suspend dari perdagangan selama tahun 2010, 2011, dan } \\
2012\end{array}$ & 0 & 129 \\
\hline 5 & Perusahaan yang listing di BEI pada tahun 2009, 2010, 2011, dan 2012 & 14 & 115 \\
\hline 6 & Data tidak tersedia & 23 & 92 \\
\hline \multicolumn{2}{|c|}{ Lama penelitian (tahun) } & & 3 \\
\hline \multicolumn{2}{|c|}{ Total sampel selama periode penelitian } & & 276 \\
\hline
\end{tabular}

\section{Statistik Deskriptif}

Nilai rata-rata untuk indikator VACA adalah 0.18886, dengan standar deviasi sebesar 0.16403 , nilai maksimum sebesar 1.27374 , dan nilai minimum sebesar -0.18136 . Nilai rata-rata tersebut menunjukkan bahwa dari setiap satu rupiah physical capital yang dimiliki perusahaan manufaktur yang terdaftar di BEI dapat menghasilkan Rp 0.18886 value added. Nilai rata-rata untuk indikator VAHU adalah 2.03359, dengan standar deviasi sebesar 2.96817, nilai maksimum sebesar 10.29641, dan nilai minimum sebesar -34.64807. Nilai rata-rata tersebut menunjukkan bahwa dari setiap satu rupiah yang dikeluarkan untuk karyawan yang dimiliki oleh perusahaan manufaktur yang terdaftar di BEI dapat menghasilkan Rp 2.03359 value added. Nilai rata-rata untuk indikator STVA adalah 0.52957, dengan standar deviasi sebesar 0.89109, nilai maksimum sebesar 7.67952, dan nilai minimum sebesar -3.72894. Nilai rata-rata tersebut menunjukkan bahwa structural capital yang dimiliki oleh perusahaan manufaktur yang terdaftar di BEI dapat memberikan kontribusi sebesar Rp 0.52957 untuk setiap value added yang diciptakan.

Nilai rata-rata untuk indikator CR adalah 6.58925, dengan standar deviasi sebesar 60.67471, nilai maksimum sebesar 1004.82254 , dan nilai minimum sebesar 0.04587 . Nilai rata-rata tersebut menunjukkan bahwa setiap Rp 1 hutang lancar yang dimiliki oleh perusahaan manufaktur yang terdaftar di BEI dapat dijamin oleh Rp 6.58925 aset lancarnya. Nilai rata-rata untuk indikator TATO adalah 1.21070, dengan standar deviasi sebesar 0.73132, nilai maksimum sebesar 5.65915, dan nilai minimum sebesar 0.03403. Nilai rata-rata tersebut menunjukkan bahwa setiap Rp 1 aset yang dimiliki perusahaan manufaktur yang terdaftar di BEI dapat menghasilkan Rp 1.21070 penjualan bersih. Nilai rata-rata untuk indikator ROI adalah 0.06331, dengan standar deviasi sebesar 0.24982 , nilai maksimum sebesar 3.47483, dan nilai minimum sebesar -1.07392. Nilai rata-rata tersebut menunjukkan bahwa setiap Rp 1 aset yang dimiliki oleh perusahaan manufaktur yang terdaftar di BEI 
dapat menghasilkan Rp 0.06331 net profit. Nilai rata-rata untuk indikator ROE adalah 0.06667 , dengan standar deviasi sebesar 0.49398, nilai maksimum sebesar 2.04696, dan nilai minimum sebesar -4.43115. Nilai rata-rata tersebut menunjukkan bahwa setiap Rp 1 modal saham biasa yang dimiliki perusahaan manufaktur yang terdaftar di BEI dapat menghasilkan Rp 0.06667 net profit.

Nilai rata-rata untuk indikator EG adalah 0.28734, dengan standar deviasi sebesar 7.38833, nilai maksimum sebesar 54.04777, dan nilai minimum sebesar -91.40147. Nilai rata-rata tersebut menunjukkan bahwa rata-rata perusahaan manufaktur yang terdaftar di BEI mengalami kenaikan net profit sebesar $28,73 \%$. Nilai rata-rata untuk indikator AG adalah 0.28086 , dengan standar deviasi sebesar 2.53567, nilai maksimum sebesar 42.10684, dan nilai minimum sebesar -0.82114. Nilai ratarata tersebut menunjukkan bahwa rata-rata perusahaan manufaktur yang terdaftar di BEI mengalami kenaikan total aset sebesar $28.09 \%$.

\section{Pengujian Outer Model Hipotesis 1 (Intellectual Capital Berpengaruh terhadap Financial Performance)}

Pada pengujian outer model, nilai T-statistic yang disarankan adalah di atas 1.96. Apabila ada indikator yang memiliki nilai di bawah itu, maka indikator tersebut harus dikeluarkan dari model dan kemudian dilakukan pengujian ulang dengan indikator yang signifikan atau mendekati signifikan. Hasil pengujian outer model untuk hipotesis 1 disajikan pada tabel dan gambar berikut:

Tabel 2 Hasil Pengujian Outer Model Hipotesis 1

\begin{tabular}{lccccc}
\hline & $\begin{array}{c}\text { Original Sample } \\
(\boldsymbol{O})\end{array}$ & $\begin{array}{c}\text { Sample Mean } \\
(\boldsymbol{M})\end{array}$ & $\begin{array}{c}\text { Standard Error } \\
(\text { STERR })\end{array}$ & $\begin{array}{c}\text { T Statistics } \\
(\mid \boldsymbol{O} / \text { STERR })\end{array}$ & $\boldsymbol{P}$ Values \\
\hline CR -> PERF & -0.804 & -0.275 & 0.551 & 1.460 & 0.145 \\
ROE -> PERF & 0.262 & 0.177 & 0.156 & 1.685 & 0.093 \\
ROI -> PERF & 0.367 & 0.490 & 0.341 & 1.078 & 0.282 \\
STVA -> VAIC & -0.069 & -0.050 & 0.069 & 1.008 & 0.314 \\
TATO -> PERF & 0.126 & 0.171 & 0.159 & 0.794 & 0.428 \\
VACA -> VAIC & 0.264 & 0.442 & 0.373 & 0.708 & 0.480 \\
VAHU -> VAIC & 0.892 & 0.439 & 0.591 & 1.510 & 0.132 \\
\hline
\end{tabular}

Sumber: Output SmartPLS

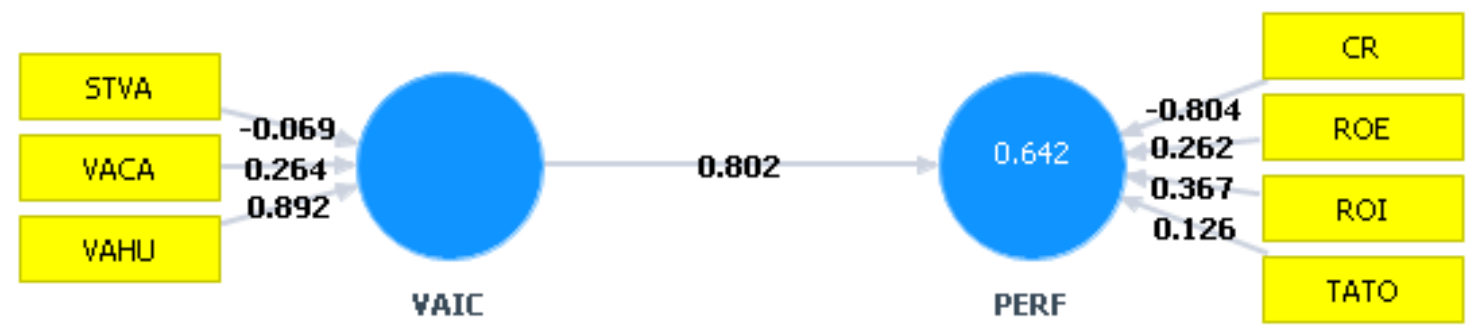

Gambar 2 Hasil Pengujian Outer Model Hipotesis 1 - Weight Sumber: Output SmartPLS 


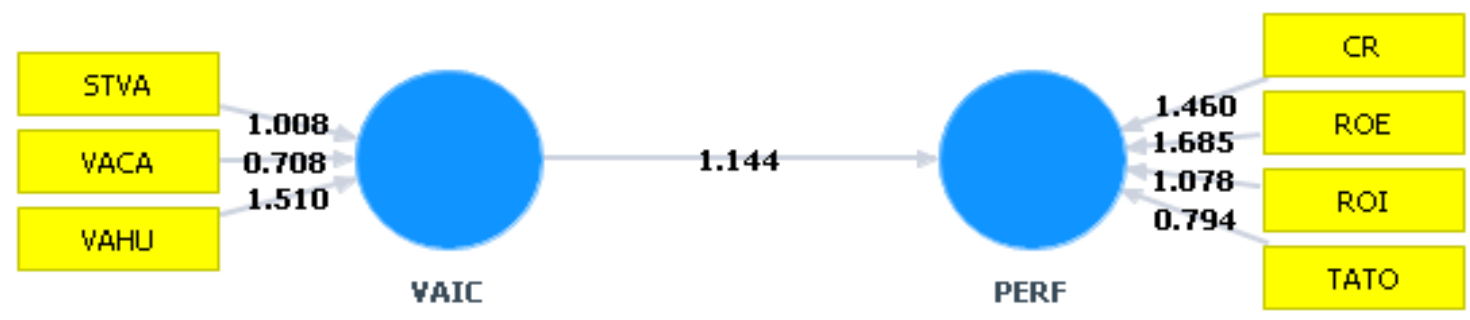

Gambar 3 Hasil Pengujian Outer Model Hipotesis 1 - T-statistic Sumber: Output SmartPLS

Berdasarkan hasil pengujian di atas, dapat dilihat bahwa semua indikator untuk variabel VAIC tidak signifikan karena memiliki nilai T-statistic di bawah 1.96, yaitu 1.008, 0.708, dan 1.510 untuk indikator STVA, VACA, dan VAHU. Semua indikator untuk variabel PERF juga tidak signifikan karena memiliki nilai T-statistic di bawah 1.96, yaitu 1.460, 1.685, 1.078, dan 0.794 untuk indikator CR, ROE, ROI, dan TATO. Karena indikator di atas memiliki nilai weight rendah dan tidak signifikan, maka perlu dilakukan pengujian ulang dengan melibatkan indikator-indikator yang mendekati signifikan. Untuk pengujian ulang, indikator yang digunakan untuk variabel VAIC yaitu VAHU karena VAHU memiliki nilai $T$-statistic yang paling mendekati 1.96 yaitu 1.510. Sedangkan untuk variabel PERF, indikator yang digunakan adalah ROE karena ROE memiliki nilai T-statistic yang paling mendekati 1.96 yaitu 1.685. Hasil pengujian ulang dapat dilihat pada gambar di bawah ini:

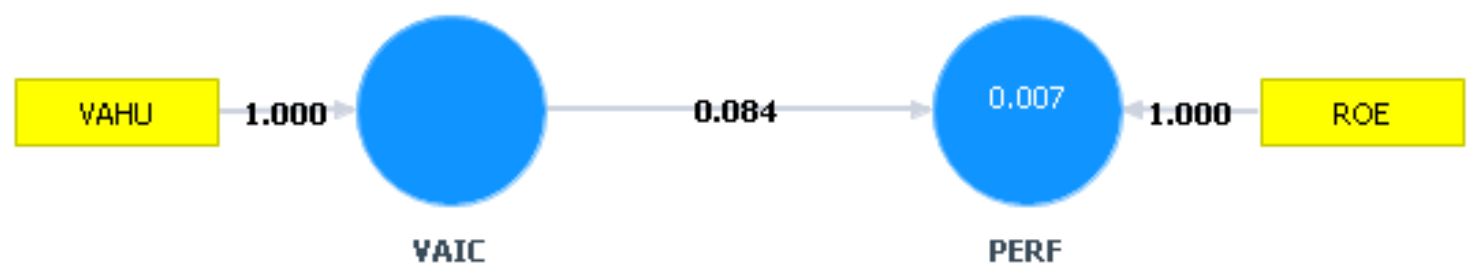

Gambar 4 Hasil Pengujian Outer Model Hipotesis 1 - Weight (Recalculate)

Sumber: Output SmartPLS

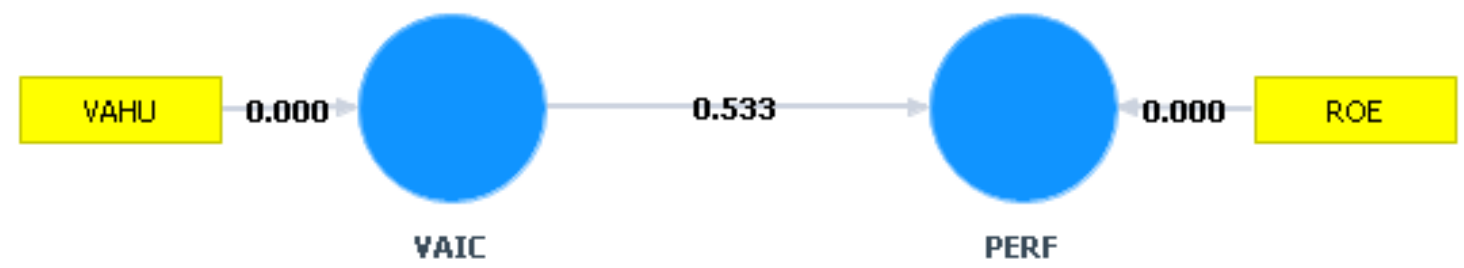

Gambar 5 Hasil Pengujian Outer Model Hipotesis 1 - T-statistic (Recalculate)

Sumber: Output SmartPLS

\section{Pengujian Inner Model Hipotesis 1}

Pada pengujian inner model, yang harus dilihat adalah nilai $R$-square dan $T$-statistic. $R$-square digunakan untuk menilai pengaruh variabel laten independen terhadap variabel laten dependen. Apabila nilai $T$-statistic di atas 1.96, maka hipotesis alternatif ( $\mathrm{Ha}$ ) diterima dan apabila nilai $T$ statistic di bawah 1.96, maka hipotesis alternatif (Ha) ditolak. Hasil pengujian inner model hipotesis 1 akan disajikan pada tabel berikut: 
Tabel 3 Hasil Pengujian Inner Model Hipotesis 1 (R-square)

\begin{tabular}{cc}
\hline \multicolumn{2}{c}{-square } \\
\hline PERF & 0.007 \\
\hline Sumber: Output SmartPLS
\end{tabular}

Tabel 4 Hasil Pengujian Inner Model Hipotesis 1 (Path Coefficients (Mean, STDEV, T-Values))

\begin{tabular}{cccccc}
\hline & $\begin{array}{c}\text { Original Sample } \\
(\boldsymbol{O})\end{array}$ & $\begin{array}{c}\text { Sample Mean } \\
(\boldsymbol{M})\end{array}$ & $\begin{array}{c}\text { Standard Error } \\
(\text { STERR })\end{array}$ & $\begin{array}{c}\text { T Statistics } \\
(|\mathrm{O} / \mathrm{STERR}|)\end{array}$ & P Values \\
\hline VAIC -> PERF & 0.084 & 0.127 & 0.157 & 0.533 & 0.595 \\
\hline
\end{tabular}

Sumber: Output SmartPLS

Berdasarkan hasil pengujian inner model di atas, dapat dilihat bahwa nilai $R$-square PERF adalah sebesar 0.007 yang artinya variabel VAIC hanya mampu menjelaskan variabel PERF sebesar $0.7 \%$. Sedangkan dari hasil pengujian di atas juga dapat dilihat bahwa nilai T-statistic untuk inner model hipotesis 1 adalah 0.533 . Nilai ini di bawah 1.96, sehingga dapat disimpulkan bahwa hipotesis 1 yaitu intellectual capital berpengaruh terhadap financial performance tidak dapat diterima.

Hasil penelitian ini sejalan dengan penelitian yang dilakukan oleh $\mathrm{Chu}$, Chan, $\mathrm{Yu}, \mathrm{Ng}, \&$ Wong (2011) di Hong Kong. Penelitian tersebut memperoleh hasil bahwa tidak ada bukti yang konklusif untuk mendukung adanya hubungan antara $\mathrm{VAIC}^{\mathrm{TM}}$ dengan empat indikator finansial yang digunakan pada penelitian tersebut, yaitu: Market to Book Value, Return on Assets, Asset Turnover, dan Return on Equity. Namun hasil penelitian ini tidak sejalan dengan penelitian yang dilakukan oleh Solikhah et. al. (2010) di Indonesia. Penelitian tersebut memperoleh hasil bahwa modal intelektual terbukti signifikan berpengaruh positif terhadap kinerja keuangan perusahaan. Selain itu, Chen et. al. (2005) melalui penelitian yang dilakukan di Taiwan juga berkesimpulan bahwa intellectual capital berpengaruh terhadap kinerja perusahaan. Menurut Zeghal \& Maaloul (2010) pada penelitian yang dilakukan di Inggris, value added intellectual coefficient mempunyai hubungan yang positif dan signifikan terhadap kinerja keuangan perusahaan. Penemuan ini mendukung peran signifikan intellectual capital dalam menciptakan nilai untuk stockholders dan stakeholders.

Dalam penelitian ini, hanya indikator VAHU yang signifikan membentuk variabel laten VAIC, sehingga hasil penelitian ini mengindikasikan bahwa sumber daya intelektual, khususnya sumber daya manusia, belum bisa menjadi kekuatan perusahaan manufaktur untuk meningkatkan kinerja keuangan perusahaan. Selain itu, faktor yang dapat mempengaruhi hasil penelitian ini adalah perusahaan manufaktur yang berkategori high-tech dengan yang berkategori low-tech belum diklasifikasikan, sehingga tidak dapat dibuktikan secara jelas apakah sumber daya intelektual bisa menjadi kekuatan perusahaan manufaktur untuk meningkatkan kinerja keuangannya. Untuk mencapai suatu kinerja keuangan yang baik, diperlukan sumber daya manusia yang pandai dalam mengelola semua sumber daya yang dimiliki perusahaan, sehingga kemungkinan diperlukan variabel mediasi untuk membuktikan bahwa intellectual capital memiliki pengaruh terhadap kinerja keuangan, seperti gaya kepemimpinan.

Selain itu, dalam penelitian ini, indikator yang signifikan membentuk variabel laten PERF adalah ROE, sehingga hasil penelitian ini menunjukkan bahwa sumber daya manusia yang dimiliki oleh perusahaan manufaktur belum bisa meningkatkan pengembalian atas investasi yang dilakukan oleh para pemegang saham. Perusahaan lebih memberikan perhatian pada upaya untuk memaksimalkan pemanfaatan aset fisik daripada pengembangan sumber daya manusia dan perusahaan belum mampu mengelola sumber daya manusianya secara maksimal untuk menciptakan value added yang akan meningkatkan kinerja keuangan perusahaan. 


\section{Pengujian Outer Model Hipotesis 2 (Intellectual Capital Berpengaruh terhadap Growth)}

Hasil pengujian outer model untuk hipotesis 2 disajikan pada tabel dan gambar berikut:

Tabel 5 Hasil Pengujian Outer Model Hipotesis 2

\begin{tabular}{|c|c|c|c|c|c|}
\hline & $\begin{array}{l}\text { Original Sample } \\
(\text { O) }\end{array}$ & $\begin{array}{c}\text { Sample Mean } \\
(M)\end{array}$ & $\begin{array}{c}\text { Standard Error } \\
\text { (STERR) }\end{array}$ & $\begin{array}{c}\text { T Statistics } \\
(\mid \text { O/STERR } \mid)\end{array}$ & $P$ Values \\
\hline AG -> GROW & -0.560 & 0.147 & 0.692 & 0.809 & 0.419 \\
\hline EG $->$ GROW & 0.831 & 0.534 & 0.446 & 1.864 & 0.063 \\
\hline STVA $->$ VAIC & -0.258 & -0.103 & 0.346 & 0.746 & 0.456 \\
\hline VACA $\rightarrow$ VAIC & 0.421 & 0.111 & 0.380 & 1.107 & 0.269 \\
\hline VAHU -> VAIC & 0.746 & 0.615 & 0.516 & 1.446 & 0.149 \\
\hline
\end{tabular}

Sumber: Output SmartPLS

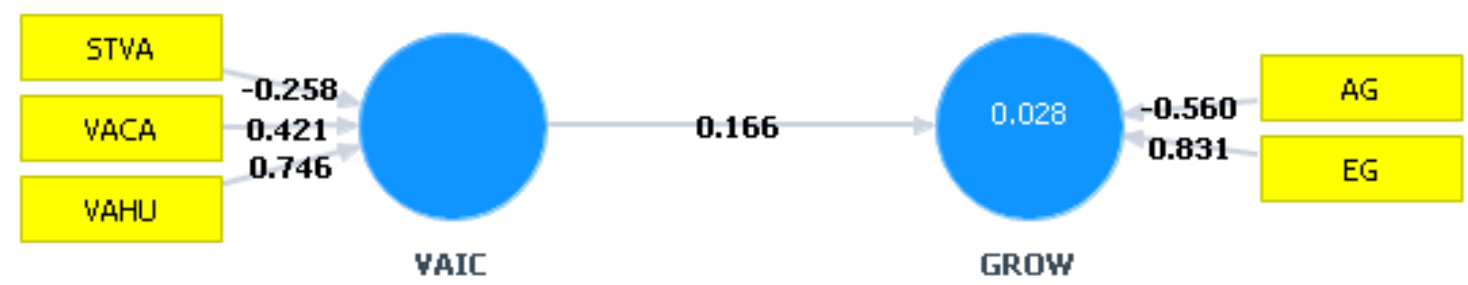

Gambar 6 Hasil Pengujian Outer Model Hipotesis 2 - Weight Sumber: Output SmartPLS

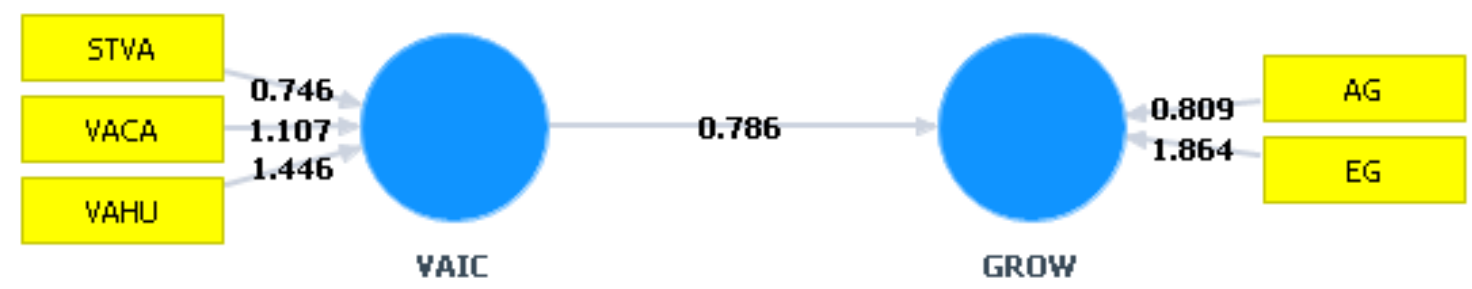

Gambar 7 Hasil Pengujian Outer Model Hipotesis 2 - T-statistic Sumber: Output SmartPLS

Berdasarkan hasil pengujian outer model hipotesis 2 di atas, dapat dilihat bahwa nilai $T$ statistic untuk semua indikator variabel VAIC, yaitu: VACA, VAHU, dan STVA masing-masing sebesar 1.107, 1.446, dan 0.746. Ketiga indikator ini memiliki nilai T-statistic di bawah 1.96 dan tidak signifikan. Sedangkan untuk indikator variabel GROW, yaitu: AG dan EG memiliki nilai T-statistic masing-masing sebesar 0.809 dan 1.864. Kedua indikator ini memiliki nilai T-statistic di bawah 1.96 dan tidak signifikan. Karena indikator di atas memiliki nilai weight rendah dan tidak signifikan, maka perlu dilakukan pengujian ulang dengan melibatkan indikator-indikator yang mendekati signifikan. Untuk pengujian ulang, indikator yang digunakan untuk variabel VAIC yaitu VAHU karena VAHU memiliki nilai $T$-statistic yang paling mendekati 1.96 yaitu 1.446 . Sedangkan untuk variabel GROW, indikator yang digunakan adalah EG karena EG memiliki nilai $T$-statistic yang paling mendekati 1.96 yaitu 1.864. Hasil pengujian ulang dapat dilihat pada gambar di bawah ini: 


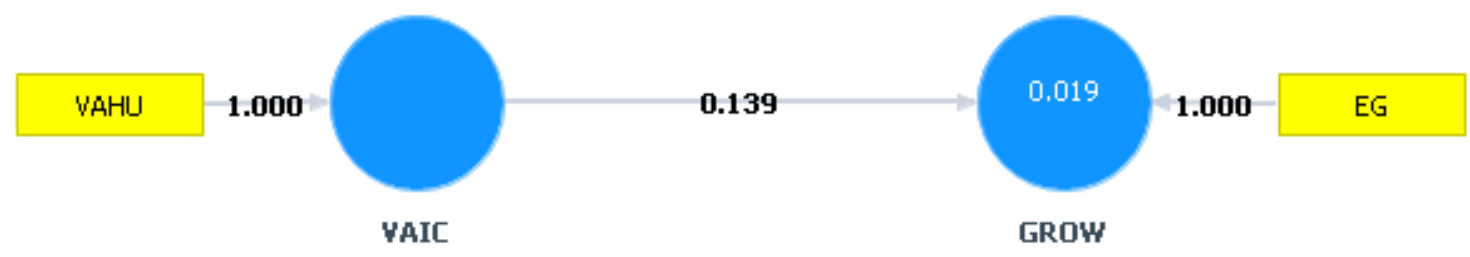

Gambar 8 Hasil Pengujian Outer Model Hipotesis 2 - Weight (Recalculate)

Sumber: Output SmartPLS

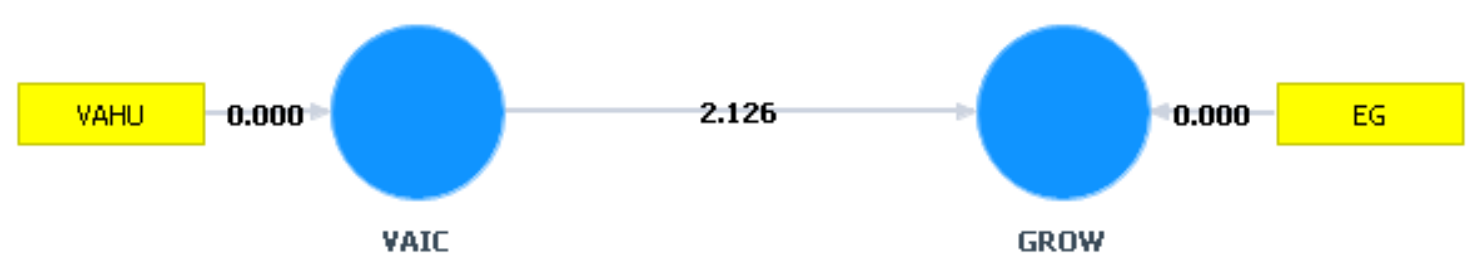

Gambar 9 Hasil Pengujian Outer Model Hipotesis 2 - T-statistic (Recalculate)

Sumber: Output SmartPLS

\section{Pengujian Inner Model Hipotesis 2}

Hasil pengujian inner model untuk hipotesis 2 akan disajikan pada tabel di bawah ini:

Tabel 6 Hasil Pengujian Inner Model Hipotesis 2 ( $R$-square)

\begin{tabular}{cc}
\hline R-square \\
\hline GROW & 0.019 \\
\hline Sumber: Output SmartPLS
\end{tabular}

Tabel 7 Hasil Pengujian Inner Model Hipotesis 2 (Path Coefficients (Mean, STDEV, T-Values))

\begin{tabular}{|c|c|c|c|c|c|}
\hline & $\begin{array}{c}\text { Original Sample } \\
(\mathrm{O})\end{array}$ & $\begin{array}{c}\text { Sample Mean } \\
(M)\end{array}$ & $\begin{array}{c}\text { Standard Error } \\
\text { (STERR) }\end{array}$ & $\begin{array}{c}\text { T Statistics } \\
(\mid \text { O/STERR } \mid)\end{array}$ & $P$ Values \\
\hline VAIC $->$ GROW & 0.139 & 0.158 & 0.065 & 2.126 & 0.034 \\
\hline
\end{tabular}

Berdasarkan hasil pengujian inner model hipotesis 2 di atas, dapat dilihat bahwa nilai estimasi pengaruh VAIC terhadap GROW adalah sebesar 0.139 dengan nilai $T$-statistic sebesar 2.126. Nilai ini lebih besar dari 1.96, sehingga dapat disimpulkan bahwa hipotesis 2 yaitu intellectual capital berpengaruh terhadap growth dapat diterima. Nilai $R$-square pada pengujian di atas adalah sebesar 0.019. Angka tersebut berarti bahwa variabel VAIC hanya bisa menjelaskan variabel GROW hanya sebesar $1.9 \%$, sedangkan sisanya $98.1 \%$ dijelaskan oleh faktor lain yang tidak diteliti pada penelitian ini. Dengan diterimanya hipotesis 2 , dapat dibuktikan bahwa semakin tinggi nilai intellectual capital maka perusahaan manufaktur akan mengalami peningkatan pertumbuhan.

Hasil penelitian ini sejalan dengan penelitian yang dilakukan oleh Solikhah et al. (2010) di Indonesia, yang menyatakan bahwa modal intelektual terbukti signifikan berpengaruh positif terhadap pertumbuhan perusahaan. Selain itu, penelitian ini juga sejalan dengan penelitian yang dilakukan oleh 
Chen et. al. (2005) di Taiwan. Penelitian tersebut berkesimpulan bahwa intellectual capital mempunyai pengaruh terhadap pertumbuhan pendapatan (revenue). Penelitian yang dilakukan oleh Diez, Ochoa, Prieto, \& Santidrian (2010) di Spanyol juga menyatakan bahwa human capital dan structural capital memiliki hubungan yang positif dengan pertumbuhan penjualan (sales). Bedanya dengan penelitian ini adalah penelitian ini meneliti pertumbuhan net profit, sedangkan kedua penelitian tersebut meneliti pertumbuhan pendapatan dan penjualan.

Dalam penelitian ini, hanya indikator VAHU yang membentuk variabel laten VAIC dan hanya indikator EG yang membentuk variabel laten GROW, sehingga dapat disimpulkan bahwa sumber daya manusia yang dimiliki oleh perusahaan manufaktur di Indonesia dapat menciptakan nilai tambah dengan memaksimalkan pengetahuan, keahlian, pengalaman, dan kemampuan yang dimiliki oleh sumber daya manusia tersebut. Nilai tambah tersebut dapat menghasilkan pertumbuhan net profit untuk perusahaan manufaktur di Indonesia. Menurut Diez et. al. (2010), kompetensi yang dimiliki oleh sumber daya manusia menghasilkan nilai melalui pengetahuan, keahlian, dan talenta. Nilai dihasilkan dari kelakuan sumber daya manusia di lingkungan kerja.

\section{SIMPULAN}

Intellectual capital tidak berpengaruh terhadap financial performance. Hal ini didukung pada pengujian inner model yang menghasilkan nilai T-statistic sebesar 0.533. Nilai ini lebih kecil dari 1.96, sehingga hipotesis 1 tidak dapat diterima. Hasil penelitian ini sejalan dengan penelitian yang dilakukan oleh Chu et. al. (2011) di Hong Kong. Namun penelitian ini tidak sejalan dengan penelitian yang dilakukan oleh Solikhah et. al. (2010) di Indonesia, Chen et. al. (2005) di Taiwan, dan Zeghal \& Maaloul (2010) di Inggris.

Intellectual capital berpengaruh terhadap growth. Hal ini didukung pada pengujian inner model yang menghasilkan nilai T-statistic sebesar 2.126. Nilai ini lebih besar dari 1.96, sehingga hipotesis 2 dapat diterima. Besarnya koefisien parameter adalah sebesar 0.139 berarti bahwa terdapat pengaruh yang postif intellectual capital terhadap growth. Semakin tinggi intellectual capital, maka growth akan semakin tinggi. Penelitian ini sejalan dengan penelitian yang dilakukan oleh Solikhah et. al. (2010) di Indonesia, Chen et. al. (2005) di Taiwan dan Diez et. al. (2010) di Spanyol.

\section{DAFTAR PUSTAKA}

Agnes, U. W. (2008). Sebuah Tinjauan Akuntansi atas Pengukuran dan Pelaporan Knowledge. 2nd National Conference UKWMS. Surabaya, 6 September 2008.

Brennan, N., Connell, B. (2000). Intellectual Capital: Current Issues and Policy Implications. Journal of Intellectual Capital, 1 (3), pp. 206-240.

Cabrita, M. R., Bontis, N. (2008). Intellectual Capital and Business Performance in the Portuguese Banking Industry. International Journal of Technology Management, 43 (1-3), pp. 212-237.

Chen, Ming-Chin, Cheng, Shu-Ju, \& Hwang, Yuhchang. (2005). An Empirical Investigation of the Relationship between Intellectual Capital and Firms' Market Value and Financial Performance. Journal of Intellectual Capital, 6 (2), 159-176. 
Chu, S. K. W., Chan, K. H., Yu, K. Y., Ng, H. T., Wong, W. K. (2011). An Empirical Study of the Impact of Intellectual Capital on Business Performance. Journal of Information \& Knowledge Management, 10 (1), pp. 11-21.

Diez, J. M., Ochoa, M. L., Prieto, M. B., Santidrian, A. (2010). Intellectual Capital and Value Creation in Spanish Firms. Journal of Intellectual Capital, 11 (3), pp. 348-367.

Ghozali, I. (2011). Structural Equation Modeling Metode Alternatif dengan Partial Least Square PLS (Edisi Ke-3). Semarang: Badan Penerbit Universitas Diponegoro.

Iswati, S., Anshori, M. (2007). The Influence of Intellectual Capital to Financial Performance at Insurance Companies in Jakarta Stock Exchange (JSE). Proceedings of the $13^{\text {th }}$ Asia Pacific Management Conference. Melbourne, Australia.

Kallapur, S., Trombley, M. A. (2001). The Investment Opportunity Set: Determinants, Consequences and Measurement. Managerial Finance, 27 (3), pp. 3-15.

Petty, R., Guthrie, J. (2000). Intellectual capital literature review: measurement, reporting and management. Journal of Intellectual Capital, 1 (2), pp. 155-176.

Pulic, A. (1998). Measuring The Performance Of Intellectual Potential In Knowledge Economy. The 2nd McMaster Word Congress on Measuring and Managing Intellectual. The Austrian Team for Intellectual Potential.

Riahi-Belkaoui, A. (2003). Intellectual Capital and Firm Performance of US Multinational Firms: A Study of the Resource-based and Stakeholder Views. Journal of Intellectual Capital, 4 (2), pp. 215-226.

Rupidara, N. (2008). Modal Intelektual dan Strategi Pengembangan Organisasi dan Sumber Daya Manusia. Diskusi Modal Intelektual Universitas Kristen Satya Wacana. Salatiga, 21 Februari 2008.

Solikhah, B., Rohman, A., Meiranto, W. (2010). Implikasi Intellectual Capital terhadap Financial Performance, Growth, dan Market Value; Studi Empiris dengan Pendekatan Simplistic Specification. Simposium Nasional Akuntansi XIII. Universitas Jenderal Soedirman. Purwokerto, 13-15 Oktober 2010.

Tan, H. P., Plowman, D., Hancock, P. (2007). Intellectual Capital and Financial Returns of Companies. Journal of Intellectual Capital, 8 (1), pp. 76-95.

Zeghal, D., Maaloul, A. (2010). Analysing Value Added as An Indicator of Intellectual Capital and Its Consequences on Company Performance. Journal of Intellectual Capital, 11 (1), pp. 39-60. 


\section{LAMPIRAN}

Tabel 1 Operasionalisasi Variabel

\begin{tabular}{|c|c|c|c|}
\hline Variabel Laten & Indikator & Fungsi & Rumus \\
\hline \multirow{3}{*}{$\begin{array}{l}\text { Intellectual } \\
\text { Capital }\left(\mathrm{VAIC}{ }^{\mathrm{TM}}\right)\end{array}$} & $\begin{array}{l}\text { Value Added } \\
\text { Capital Employed } \\
\text { (VACA) }\end{array}$ & $\begin{array}{l}\text { Untuk menunjukkan berapa banyak } \\
\text { value added (VA) yang dihasilkan } \\
\text { dari satu unit physical capital }\end{array}$ & $\begin{array}{l}\text { VACA = (Operating Profit } \\
+ \text { Employee Costs }) / \text { Capital } \\
\text { Employed }\end{array}$ \\
\hline & $\begin{array}{l}\text { Value Added } \\
\text { Human Capital } \\
\text { (VAHU) }\end{array}$ & $\begin{array}{l}\text { Untuk menunjukkan berapa banyak } \\
\text { value added (VA) yang dihasilkan } \\
\text { dari satu unit dana yang } \\
\text { dikeluarkan untuk karyawan }\end{array}$ & $\begin{array}{l}\text { VAHU }=(\text { Operating Profit } \\
+ \text { Employee Costs }) / \\
\text { Employee Costs }\end{array}$ \\
\hline & $\begin{array}{l}\text { Structural Capital } \\
\text { Value Added } \\
\text { (STVA) }\end{array}$ & $\begin{array}{l}\text { Untuk menunjukkan kontribusi } \\
\text { structural capital (SC) dalam } \\
\text { penciptaan nilai (value creation) }\end{array}$ & $\begin{array}{l}\text { STVA = Operating Profit / } \\
\text { (Operating Profit }+ \\
\text { Employee Costs })\end{array}$ \\
\hline \multirow{4}{*}{$\begin{array}{l}\text { Financial } \\
\text { Performance }\end{array}$} & Current Ratio (CR) & $\begin{array}{l}\text { Untuk mengukur kemampuan } \\
\text { perusahaan dalam memenuhi } \\
\text { kewajiban jangka pendek }\end{array}$ & $\begin{array}{l}\mathrm{CR}=\text { Current Assets / } \\
\text { Current Liabilities }\end{array}$ \\
\hline & $\begin{array}{l}\text { Total Assets } \\
\text { Turnover (TATO) }\end{array}$ & $\begin{array}{l}\text { Untuk mengukur efisiensi } \\
\text { perusahaan menggunakan asetnya } \\
\text { untuk memperoleh penjualan }\end{array}$ & TATO $=$ Sales $/$ Total Assets \\
\hline & $\begin{array}{l}\text { Return on } \\
\text { Investment (ROI) }\end{array}$ & $\begin{array}{l}\text { Untuk mengukur efektivitas } \\
\text { manajemen secara keseluruhan } \\
\text { dalam memperoleh profit dengan } \\
\text { menggunakan aset yang ada }\end{array}$ & $\begin{array}{l}\mathrm{ROI}=\text { Earnings available } \\
\text { for common stockholders / } \\
\text { Total Assets }\end{array}$ \\
\hline & $\begin{array}{l}\text { Return on Equity } \\
\text { (ROE) }\end{array}$ & $\begin{array}{l}\text { Untuk mengukur pengembalian } \\
\text { yang dihasilkan dari investasi para } \\
\text { pemegang saham biasa di } \\
\text { perusahaan }\end{array}$ & $\begin{array}{l}\mathrm{ROE}=\text { Earnings available } \\
\text { for common stockholders / } \\
\text { Common stock equity }\end{array}$ \\
\hline \multirow{2}{*}{ Growth } & $\begin{array}{l}\text { Earnings Growth } \\
\text { (EG) }\end{array}$ & Untuk mengukur pertumbuhan laba & 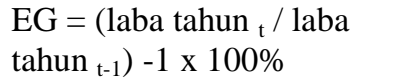 \\
\hline & $\begin{array}{l}\text { Assets Growth } \\
(\mathrm{AG})\end{array}$ & Untuk mengukur pertumbuhan aset & $\begin{array}{l}\mathrm{AG}=\left(\text { aset tahun }_{\mathrm{t}} / \text { aset }\right. \\
\left.\operatorname{tahun}_{\mathrm{t}-1}\right)-1 \times 100 \%\end{array}$ \\
\hline
\end{tabular}

Tabel 2 Sampel Penelitian Berdasarkan Industri

\begin{tabular}{lc}
\hline \multicolumn{1}{c}{ Jenis Industri } & Jumlah Perusahaan \\
\hline Basic Industry and Chemicals & $\mathbf{3 7}$ \\
Cement & 2 \\
Ceramics, Glass, and Porcelain & 5 \\
Metal and Allied Products & 11 \\
Chemicals & 4 \\
Plastics and Packaging & 8 \\
Animal Feed & 2 \\
Wood Industries & 1 \\
Pulp and Paper & 4 \\
Miscellaneous Industry & $\mathbf{3 2}$ \\
Machinery and Heavy Equipment & 0 \\
Automotive and Components & 9 \\
Textile and Garment & 15 \\
Footwear & 2 \\
Cable & 5 \\
Electronics & 1 \\
\hline
\end{tabular}


Tabel 2 Sampel Penelitian Berdasarkan Industri (lanjutan)

\begin{tabular}{lc}
\hline \multicolumn{1}{c}{ Jenis Industri } & Jumlah Perusahaan \\
\hline Consumer Goods Industry & $\mathbf{2 3}$ \\
Food and Beverages & 10 \\
Tobacco Manufacturers & 2 \\
Pharmaceuticals & 6 \\
Cosmetics and Household & 2 \\
Houseware & 3 \\
\hline TOTAL & $\mathbf{9 2}$ \\
\hline \multicolumn{2}{c}{ Sumber: Hasil olahan }
\end{tabular}

Tabel 3 Statistik Deskriptif Intellectual Capital $\left(\mathrm{VAIC}^{\mathrm{TM}}\right.$ )

\begin{tabular}{lcccc}
\hline \multicolumn{1}{c}{ Indikator } & $\begin{array}{c}\text { Rata- } \\
\text { rata }\end{array}$ & $\begin{array}{c}\text { Standar } \\
\text { Deviasi }\end{array}$ & $\begin{array}{c}\text { Nilai } \\
\text { Maksimum }\end{array}$ & $\begin{array}{c}\text { Nilai } \\
\text { Minimum }\end{array}$ \\
\hline Value Added Capital Employed (VACA) & 0.18886 & 0.16403 & 1.27374 & -0.18136 \\
Value Added Human Capital (VAHU) & 2.03359 & 2.96817 & 10.29641 & -34.64807 \\
Structural Capital Value Added (STVA) & 0.52957 & 0.89109 & 7.67952 & -3.72894 \\
\hline
\end{tabular}

Sumber: Hasil olahan

Tabel 4 Statistik Deskriptif Financial Performance

\begin{tabular}{lcccc}
\hline \multicolumn{1}{c}{ Indikator } & Rata-rata & Standar Deviasi & Nilai Maksimum & Nilai Minimum \\
\hline Current Ratio (CR) & 6.58925 & 60.67471 & 1004.82254 & 0.04587 \\
Total Assets Turnover (TATO) & 1.21070 & 0.73132 & 5.65915 & 0.03403 \\
Return on Investment (ROI) & 0.06331 & 0.24982 & 3.47483 & -1.07392 \\
Return on Equity (ROE) & 0.06667 & 0.49398 & 2.04696 & -4.43115 \\
\hline
\end{tabular}

Sumber: Hasil olahan

Tabel 5 Statistik Deskriptif Growth

\begin{tabular}{lcccc}
\hline \multicolumn{1}{c}{ Indikator } & Rata-rata & Standar Deviasi & Nilai Maksimum & Nilai Minimum \\
\hline Earnings Growth (EG) & 0.28734 & 7.38833 & 54.04777 & -91.40147 \\
Assets Growth (AG) & 0.28086 & 2.53567 & 42.10684 & -0.82114 \\
\hline
\end{tabular}

Sumber: Hasil olahan 